\title{
茶白紋羽病防除薬剤としてのチオファネート
}

\author{
メチルおよびベノミル剤
}

農林省茶業試験場高屋茂雄・福田德治 笠井久三・大池康子

京都府立茶業研究所吉田輝久

神奈川県農業総合研究所近岡一郎

神奈川県伊勢原農業改良普及所 加藤 正一

\section{Effects of Thiophanate-Methyl and Benomyl against \\ White Root Rot of Tea}

\author{
By Shigeo TAKAYA, Tokuji FukUdA, Kyuzo KASAI and Yasuko ÔIKE \\ National Research Institute of Tea \\ Teruhisa YosHIDA
}

Kyoto Prefectural Tea Research Institute

Ichiro CHIKAOKA

Kanagawa Prefectural Agricultural Experiment Station

Shoichi KATO

Kanagawa Prefectural Isehara Agricultural Extension Office

\section{1 ま がき}

茶白紋羽病の薬猟防除法としては，クロルピクリン郕 を用いる方法がすでに確立されている。しかし，クロル ビクリン剂は劇物で，取り扱いに注意を要し，実際に士 裹に処理する作業も容易ではないために，これに代り5 る薬凩の出現が望まれていた。 1973年〜75 年の 3 カ年にわたって，全国茶農䒚連絡試 験に, 茶白紋羽病に対するチオフフネートメチルおよび ベノミル阂の效果の判定が委託され，農林省茶試および 京都茶研が試験を担当した。農林省茶試の試験の一部 は，神奈川県秦野市に本病の激発した茶疅があったこと
から，神奈川県の関係機関との共同試験として害施し た。それらの結果は，すでに全国茶農薬連絡試験成績検 討会の席上で報告したが，上記の 2 薬蝺は，効果の点に ついては茶白紋羽病の防除に使用できる見通しが得られ たので，試験の概要をとりまとめて報告する。

\section{2 実 験 方 法}

供試薬剤の有效成分および含量は表 1 に示した。

り病根は自然発病した茶樹から切断した太さ $5 \sim 10 \mathrm{~mm}$ 長さ $2 \sim 3 \mathrm{~cm}$ 程度のものを用いた。

楽剤の土襄処理は, 室内試験では $5 \mathrm{~mm}$ の穊を通した 土塆 $500 \mathrm{~m} l$ K, 所定の楽液を十分混ぜあわせたのち，ブ

表1供試薬剂の有効成分および含量

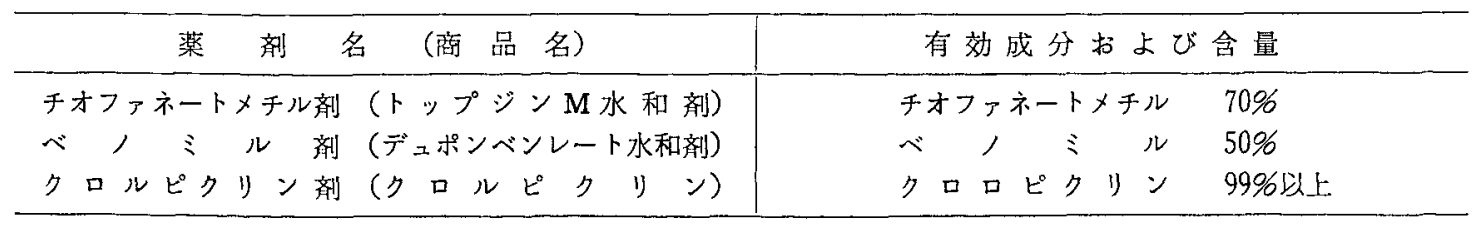




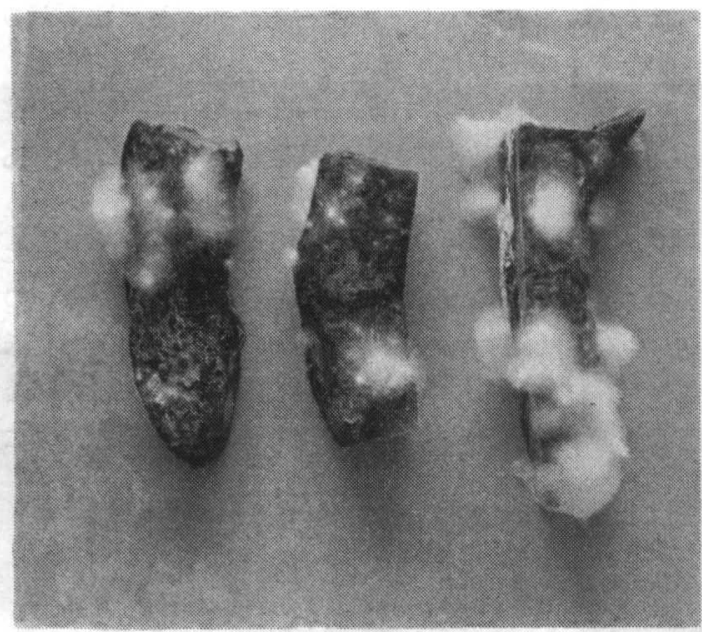

写真1 り病根片加らの菌系の発生 (23 $28^{\circ} \mathrm{C}$, 湿室 $5 \sim 7$ 日)

ラスチック製の箱につめこんだ。ほ場試験では畑のなか で $1 \mathrm{~m}^{2}$ の面積を区切って所定の薬液を土壇とよくかく はんしながら潅注し, 少なくとも深さ $30 \mathrm{~cm}$ までは, 薬 液が十分行きわたるようにした。

り病根中における白紋羽病菌の生存は, 処理が終了し たり病根を水道水で十分洗浄した後， $23 \sim 28^{\circ} \mathrm{C}$ の湿室 に $5 \sim 7$ 日間保持し, 発生した菌系の Swelling の有無 によって白紋羽病菌かどうかを判定した。(写真 1，2）

感染幼茶樹の薬液浸漬による治療勃果は, 白紋羽病に り病した幼木を掘り上げ,つつぎのよ 5 な基準によって軽 症および重症の 2 つに分け, 所定の薬液に浸漬したのち 畑に再定植して，その後の状況を観察した。

軽症：中根以上の根の一部に明瞭な病斑部を持つが, 病斑の拡大が，この程度で停止すれば以後の生育には差 しつか竞ないと思われるもの。

重症：な捄生きてはいるが, 病斑が拡大しており,こ のままでは枯死すると思われるるの。

\section{3 実 験 結 果}

\section{1 り病根を藥液に浸漬した場合の殺菌効果}

り病根を薬液に浸漬したのち, それらのり病根におけ る白紋羽病菌の生存状況を調查した結果は表 2 のと沏り である。

り病根片を薬液に浸漬した場合には, 両薬剤とも， 5000倍でも高い殺菌効果を示した。

\section{2 薬液を処理した土壤中にり病根を埋めこんだ}

\section{場合の殺菌効果（室内試験）}

薬液を均一に処理した少量の土壌中にり病根を埋没 し, それらのり病根に扮ける白紋羽病菌の生存状況を調 查した結果は表 3 のと扣りである。

試験 1 ではトッブジンM水和風は, 700倍, 1500 倍とも $に 100 \mathrm{ml} /$ 土壌 $0.5 l$ の処理量でも十分な殺菌効果は得ら

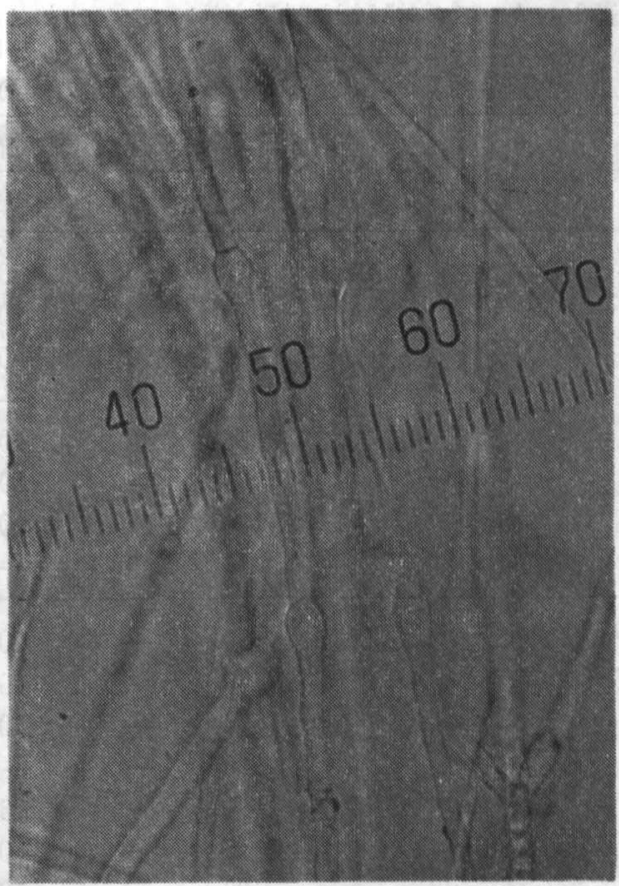

写真 2 白紋羽病菌菌系の Swelling

表 2 トップジンMおよびデュポンベンレート水和 剂の薬液中に浸漬したり病根中における白紋羽 病菌の生存（24時間浸漬）

\begin{tabular}{|c|c|c|c|}
\hline \multirow{2}{*}{ 薬剂および濃度 } & & \multicolumn{2}{|c|}{ 白紋羽病菌の生存率 } \\
\hline & & 試 験 1 & 試 験 2 \\
\hline トップジン M水和剂 & $\begin{array}{r}\text { 倍 } \\
700\end{array}$ & $\begin{array}{l}\% \\
0\end{array}$ & 96 \\
\hline " & 1500 & 0 & 0 \\
\hline " & 3000 & 0 & 0 \\
\hline$"$ & 5000 & - & 10 \\
\hline デュポンベンレート水和剂 & 3000 & - & 0 \\
\hline " & 5000 & - & 0 \\
\hline 対 照 (水) & & 70 & 100 \\
\hline
\end{tabular}

れなかった。しかし, 試験 2 では, 両楽風の両濃度とも $100 \mathrm{~m} l /$ 土壤 $0.5 l$ の処理は強い殺菌効果を示した。

\section{3 り病根を埋めこんだ土壤に薬液を潅注した場 合の殺菌効果（ほ場試験）}

ほ場において,り病根を埋めこんだのち，所定の薬液 を潅注し，それらのり病根中における白紋羽病菌の生存 状況を調查した結果は表 4 のとおりである。

両薬風, 両濃度とも, $1 \mathrm{~m}^{2}$ あたり $20 l$ の処理では殺 菌効果はほとんど認められなかったが, $1 \mathrm{~m}^{2}$ あたり $40 l$ を処理すると，菌の生存率は無処理に比べてかなり低下 し，とくにトップジン $\mathrm{M}$ 水和剤 700 倍およびデュポンべ ンレート水和剤 1000 倍の処理区では, 菌の生存率は対照 としたクロルピクリンと，少なくとも同等であった。 
表 3 トップジンMおよびデュポンベンレート水和 剂を均一に炕理した少量の土䇎中に理没したり 病根中における白紋羽病菌の生存（室内試験）

\begin{tabular}{|c|c|c|c|c|}
\hline \multirow{2}{*}{ 薬 } & \multirow{2}{*}{ 濃度 } & \multirow{2}{*}{$\begin{array}{l}\text { 土壤0.5l } \\
\text { に対する } \\
\text { 処 理 量 }\end{array}$} & \multicolumn{2}{|c|}{ 白紋羽病菌の生存率 } \\
\hline & & & 試 験 1 & 試 験 2 \\
\hline \multirow{8}{*}{ 永ップジンM } & 700 & $\begin{array}{r}\mathrm{ml} l \\
50\end{array}$ & $\begin{array}{l}\% 6 \\
56\end{array}$ & $\begin{array}{l}86 \\
50\end{array}$ \\
\hline & & 75 & - & 0 \\
\hline & & 100 & 50 & 0 \\
\hline & & 200 & 0 & - \\
\hline & 1500 & 50 & 40 & 60 \\
\hline & & 75 & - & 50 \\
\hline & & 100 & 20 & 0 \\
\hline & & 200 & 0 & - \\
\hline \multirow{8}{*}{$\begin{array}{l}\text { デュポソベンレ } \\
\text { ート水和 剂 }\end{array}$} & 2000 & 50 & - & 10 \\
\hline & & 75 & 一 & 20 \\
\hline & & 100 & - & 10 \\
\hline & & 200 & - & 一 \\
\hline & 3000 & 50 & - & 90 \\
\hline & & 75 & - & 50 \\
\hline & & 100 & - & 10 \\
\hline & & 200 & - & 一 \\
\hline 対 照 (水) & & $\begin{array}{c}75 \text { また } \\
\text { は100 }\end{array}$ & 67 & 80 \\
\hline
\end{tabular}

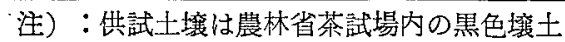
り病根の埋没は $24^{\circ} \mathrm{C}$ ，48時間。

表 4 トップジンM抢よびデュポンベンレート水和 剂を潅注した土壤中に埋没したり病根中におり る白紋羽病菌の生存（ほ場試験）

\begin{tabular}{|c|c|c|c|c|}
\hline \multirow{2}{*}{ 薬 } & \multirow{2}{*}{ 濃 度 } & \multirow{2}{*}{ 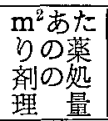 } & \multicolumn{2}{|c|}{ 白紋羽病菌の生存率 } \\
\hline & & & 試験 1 & 試 験 2 \\
\hline \multirow{2}{*}{ 水” } & 700 & $\begin{array}{c}l \\
20\end{array}$ & $\begin{array}{l}96 \\
50\end{array}$ & 90 \\
\hline & $"$ & 40 & 10 & 0 \\
\hline \multirow[t]{2}{*}{$"$} & 1500 & 20 & 90 & 87 \\
\hline & $n$ & 40 & 60 & 28.6 \\
\hline \multirow{4}{*}{$\begin{array}{l}\text { デュポソベンレ } \\
\text { ート水和剂 }\end{array}$} & 1000 & 20 & 90 & 55.2 \\
\hline & $"$ & 40 & 10 & 35.3 \\
\hline & 2000 & 20 & 80 & 83.3 \\
\hline & $"$ & 40 & 20 & 55.6 \\
\hline \multirow{2}{*}{$\begin{array}{l}\text { クロルピクリン } \\
\text { 無玑理 }\end{array}$} & （対照） & 1 穴 $4 \mathrm{ml}$ & 0 & 40.9 \\
\hline & & & 70 & 86.1 \\
\hline
\end{tabular}

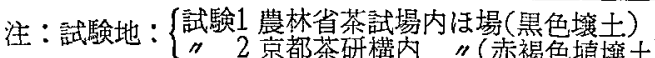

薬剂処理：試験 11974.9 .14

" 21974.4 .25

り涡根の掘り上げ：試験 1 1974.9.28

" 21974.5 .24

り病根を埋めとんだ深さは $15 〜 20 \mathrm{~cm} 。$ クルピクリ ン処理区については，り病根を埋めてんだ場所から $15 \mathrm{~cm}$ 離れたこころの，深さ $10 \mathrm{~cm} の$ 位置に薬液を好理し，ポ リエチレン布で被㠅した。
また発病跡地で，トップジンM水和剤を潅注したの ち，土滖中に残存していたり病根または本病菌の付着し ていた粗た（柔）を掘り上げ，それらの中に拁ける白紋 羽病菌の生存状況を調查した結果は表 5 のと㧍りであ 万o

この試験にお゙いても，トッブジン M 水和剤を潅注した 区の，深さ 10〜20 cm のところから探取したり 病根中の 菌の生存率は，クロルピクリン区と同等で，きわめて低 かった。しかし，薬同の効果は深さ $40 \mathrm{~cm}$ までは達しな いよ5でこの付近から掘り上げたり病根または粗た中に は，きわめて高率で菌が生存していた。

表 5 トップジンM水和剂を短注した発病跡地に残 存していたり病根またはそだ中における白紋羽 病菌の生存

\begin{tabular}{|c|c|c|c|}
\hline 薬 & $\begin{array}{l}\text { 濃度および } \\
\text { 処理 量 }\end{array}$ & $\begin{array}{l}\text { り病根な } \\
\text { よ゙を採取 } \\
\text { した湫さ }\end{array}$ & $\begin{array}{l}\text { 白紋羽 } \\
\text { 病囷の } \\
\text { 生存率 }\end{array}$ \\
\hline トップジンM水和剂 & 700 倍 $40 l / \mathrm{m}^{2}$ & $\begin{array}{c}10 \sim 20 \mathrm{~cm} \\
\text { 約 } 40\end{array}$ & $\begin{array}{l}20 \% \\
95\end{array}$ \\
\hline $\begin{array}{c}\text { クロルピクリン } \\
\text { (対 照) }\end{array}$ & $5 \mathrm{ml} /(30 \mathrm{~cm})^{2}$ & $\begin{array}{l}10 \sim 20 \\
\text { 約 } 40\end{array}$ & $\begin{array}{r}20 \\
100\end{array}$ \\
\hline 無 処 理 & & $10 \sim 20$ & 100 \\
\hline
\end{tabular}

試 験 地：静岡県掛川市（赤裀色埴埕土）

薬剂処理: 1973.9.17

り病根の採取：1973.10.4

クロルピクリン注入区はポリエチレン布で被覆した。

\section{4 白紋羽病に感染した幼茶樹の薬剤浸潰による 治療効果}

供試した雨楽隹は，薬液中にり病根を浸漬すると，そ の中に生存している 白紋羽病菌に対して強い殺菌力を示 すことが明らかになったので，さらに新しい試みとし て，本病に感染した幼茶樹の薬液浸漬による治療効果を 検討した。試騟期間中の各区の幼木の枯死㧍よび生育状 況は表 6 のとおりである。

試験 1 では刘照区を含めて試験期間中に枯死した幼木

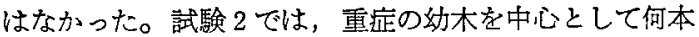
かの枯死株がみられたが，中間調查の際にみられた枯死 株はいずれる 寒干害によるものと判定した。最終調查の 際にみられた枯死または枯死直前株の5ち無処理区の 1 株は，明らかに白紋羽病によって枯死したるのであっ た。しかしその他のるのは枯死または生育不良の生じた 原因が，本病の病斑桩大によるものとは思われなかっ た。

このよ5に，2 回の試験ともに，無処理の幼木でも本 病の病斑扰大によって枯死に至ったものはきわめてわず かであったが，最終調查の際，すべての株について，根 部に拈ける 白紋羽病菌菌系のてん絡状況を観察した結果 
表 6 薬液浸漬による白秝羽病の治療勃果試験期間中の各区の幼木の枯死および生育状況

\begin{tabular}{|c|c|c|c|c|c|c|c|c|c|c|}
\hline \multirow{3}{*}{ 蔝 } & \multirow{3}{*}{ 剂 } & \multirow{3}{*}{ 溲 度 } & \multirow{3}{*}{ 発病程度 } & 試 & 1 & \multicolumn{3}{|c|}{ 試 } & \multicolumn{2}{|l|}{2} \\
\hline & & & & \multirow{2}{*}{ 供試株数 } & \multirow{2}{*}{$\begin{array}{l}\text { 最終調查 } \\
\text { c゙枯 } \\
\text { 死株数 }\end{array}$} & \multirow[b]{2}{*}{ 供試株数 } & \multirow{2}{*}{$\begin{array}{l}\text { 中聞調查 } \\
\text { Ф際の枯 } \\
\text { 死株 数 }\end{array}$} & 最 & 終 & 烃 \\
\hline & & & & & & & & $\begin{array}{l}\text { 枯死また } \\
\text { 枯死㨁 } \\
\text { 前株 数 }\end{array}$ & $\begin{array}{l}\text { 生去不良 } \\
\text { 数 }\end{array}$ & 告育后好 \\
\hline \multirow{3}{*}{\multicolumn{2}{|c|}{ 水ップジンM }} & 700 倍 & 軽症 & 4 & 0 & 23 & 0 & 5 & 5 & 13 \\
\hline & & $n$ & 重症 & - & - & 7 & 2 & 2 & 3 & 0 \\
\hline & & 1500 & 軽症 & 4 & 0 & 5 & 1 & 2 & 2 & 0 \\
\hline \multirow{3}{*}{\multicolumn{2}{|c|}{ 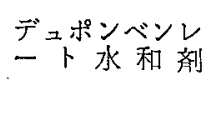 }} & 1000 & 俥症 & 4 & 0 & 23 & 3 & 2 & 5 & 13 \\
\hline & & $"$ & 重症 & - & - & 7 & 4 & 3 & 0 & 0 \\
\hline & & 2000 & 軽症 & 4 & 0 & 5 & 0 & 1 & 0 & 4 \\
\hline & 理 & & 軽症 & 3 & 0 & 5 & 2 & $1^{*}$ & 1 & 1 \\
\hline
\end{tabular}

注：*：白紋羽病による枯死。その他は，白紋羽病以外の原因で枯死したものとした。

試 験 地 $\left\{\begin{array}{cl}\text { 試験 } 1 & \text { 農林省茶試場内 } \\ 1 & 2\end{array}\right.$ 神奈川県䒳野市（赤褐色砂壤土）

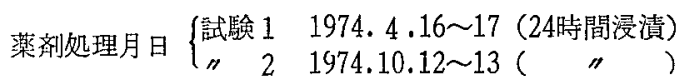

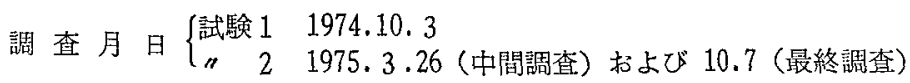

表 7 薬液浸漬による白紋羽病治療効果試験，最終調查における各区の幼木根部の本病菌菌系のてん絡状況

\begin{tabular}{|c|c|c|c|c|c|c|}
\hline \multirow[b]{2}{*}{ 薬 } & \multirow[b]{2}{*}{ 濃度 } & \multirow[b]{2}{*}{ 発病程度 } & 試 & 験 1 & 試 & 験 $\quad 2$ \\
\hline & & & 調查株数 & 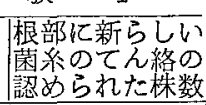 & 調査株数 & $\begin{array}{l}\text { 根部に新らしい } \\
\text { 菌系のて絡の } \\
\text { 認められた株数 }\end{array}$ \\
\hline \multirow[t]{3}{*}{ トップジン $\mathrm{M}$ 水和 剂 } & 700倍 & 軽症 & 4 & 0 & 23 & 1 \\
\hline & " & 重症 & - & - & 7 & 0 \\
\hline & 1500 & 整症 & 4 & 0 & 5 & 1 \\
\hline \multirow[t]{3}{*}{ デュポンベンレート水和剂 } & 1000 & 軽症 & 4 & 0 & 20 & 0 \\
\hline & $" \prime$ & 重症 & - & 一. & 3 & 0 \\
\hline & 2000 & 軽淀 & 4 & 0 & 5 & 0 \\
\hline 処 & & 轻症 & 3 & 2 & 3 & $\dot{3}$ \\
\hline
\end{tabular}

は表7のと㧍りである。

試験 1 では, 無処理区の幼木す新生細根がよく発生し. 充(㯖)死部が拡大したよ5には思われなかった。しかし， 3 本の 5 ち 2 本の奻木の根部には白色の白紋羽病菌菌系 がてん絡しており，菌の生存が確認された。

薬鄅浸清を行なったものは，各区ともすべての奻木で 新生細根をよく形成し，根部には，白紋羽病菌の菌系は まったく認められなかった。

試験 2 でも，軽症の地上部の生育の 良好な株は烺部の 生育もよく新生細根がよく発生していた。

無始理区では菌系の密度に多少の差はあったが，いず れの株の根部にも菌系のてん絡が認められだ。一方薬凨 処理区では，トップジンM水和剤処理区でわずかに菌系 が認められたが，デュポンベンレート水和冏区ではまっ たく㒛められなかった。

な扮，奻木を薬液汇浸漬しても薬害はなかった。

\section{4 考 察}

発病現地に打ける萊白紋羽病の薬剂防除試験には困難 が多い。その理由は，試験の可能な面皘に均一な発病が みられるような莱園が少ないことと，仮りにそのような 茶園がみつかっても，一般に，所有者は早く齐策を講じ ることを要望し，効果の判然としない薬剂を使用与る区 や無処理区の設置にあまり好意的ではないためである。

そこで，発病現地以外のところで，薬刱の効果を判定 する方法として、すでに記したようないくつかの誹験を 行なった。

その結果，トップジンM扰よびデュポンベンレート水 和阂はり病根中に生存する菌に対して，り病根を䍒液に 漫清した場合には強い殺菌力を示した。土壤に潅注する 場合については，とくに処理量が問題で文り， $1 \mathrm{~m}^{2}$ あた り $40 l く ら い の$ 薬液が海注でされば，少なくとも薬液と 
土培とが十分混和できる範国内のり病根に対しては，か なりの殺菌效果を持っていることが判明した。

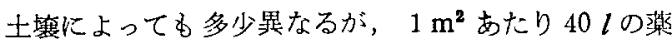
液を潅注すると深さ $20 \sim 30 \mathrm{~cm}$ の籍囲までの土塆は泥权 い(寧) の状態になるが，確実な殺菌効果を得るために は，このような状態になるまで薬液を妈理することが必 要であり，広い範囲にわたって，土整の梁部までこのよ らな姏理を行ならことは事实上不可能である。しかし小 範囲の, 例えば $2 \sim 3$ 本の発病幼木を掘り上げな跡地の

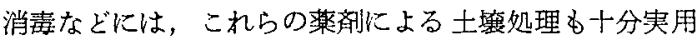
に供し5るるのと思われた。

実験の結果，このよ5な㚮理区に拈いてもな拈，いく らかのり病根中には菌の生存しているものがみられたが， これらの菌を完全に般菌できなくても，菌の密度が低下 すれば，薬凩好理の実用的な効果が得られることは，ク ロルピクリンとの比較からす明らかであった。本病防除 薬㓮として実際に使用され，実用上十分な效果を括さめ ているクロルピクリン処理区でも，なお一部のり病根中 に菌が生存していた。

また新しい試みとして行った感染奻茶樹の薬液浸清に よる治療効果試験については，このような処理を実際に 必要とする場面がきわ力て限られていることは，著者ら の，これまでの経験からも明らかである。しかし，この ような技術が確立できれば，これまで，陞却せざるを得 なかった感染奻茶樹が助かることになり，農家の人々の 感じる心理的な負担が，軽減されるるのと思われた。

本病にり病した奻茶樹の5ち，感染程度の軽いるの は、把りとって移植するたけけでも病勢を著るしくそぐよ 5であり，2回の試験ともに，予想したよ5な好結果は 得られなかったが，少なくとも無好理区の幼木の根部に は，移植後も，本病菌の菌系のてん絡が認められたのに 対して，薬用処理区では，菌糸の認められたものはごく 少数であったことから，感染奻茶樹に刘してこれら両薯 剤の薬液浸漬は有効であると判定した。

なお，トップジン M とデュポンベンレート水和風は受 託年次の関保で，必ずしも平行した試験が行われていな いが，浸漬試験の結果などから，両者の効果は医湾同等 であるとして将察を行なった。

\section{5 要 約}

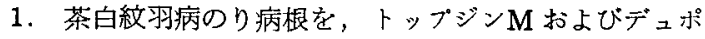
ンペンレート水和剤の薬液に 24 時間浸漬すると，両楽 郕と65000倍でも，り病根中に生存する病原菌に対し て，強い殺菌効果を示した。

2. トッブジンM水和郕700倍怙よびデュポンベンレート 水和剂1000倍液を $1 \mathrm{~m}^{2}$ あたり $40 l$ の割合で処理した土 壤では，薬液と土堙とがよく混和された範囲のり病根 中の菌の生存率は，対照としたクロルピクリン処理区

\section{と同等程度に低下していた。}

3. 2 と同濃度の薬液に 24 時間浸漬し，定植した感染幼 茶樹の根部に，半年〜 1 年後，無処理の奻木に見られ たような病原菌の菌綀が観察されたものはきわめて 少数であり，薬害もなかった。

4. 以上のことから，これらの薬剂による土培好理は本 病に対して存効であり，発病が小範囲であれば，实用

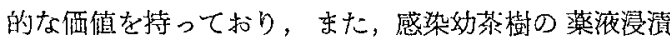
処理も有效であると判定した。

本奏験の遂行にあたっては，神奈川県中部病等蚄除 所のご協力をいただき，また松浦 博氏，増田一郎氏に は試験ほ場を，日本曹達株式会社 およびデュポン・フ ーイースト日本支社には薬剤を提供していたたいた。記 して感謝の意を表します。

\section{6 引用文 献}

1）笠井久三，高屋茂雄，広川敢：苯技研：No. 32, $34 \sim 44$ (1966).

2）日本植物防滰協会：茶農薬連絡試験成績（1973～ '75).

\section{Summary}

1. Pieces of infected tea root of white root rot were dipped in water solutions of thiophanatemethyl (Topsin-M, ingredient 70\%) and benomyl (Benlate, ingredient 50\%) for $24 \mathrm{hr}$. Mycelium growth of the causal fungus from treated roots was nearly inhibited at concentrations higher than $1: 5000$ dilution in both fungicides.

2. Water solutions of Topsin-M (diluted 1:700) and Benlate (diluted $1: 1000$ ) were irrigated into soil at the rate of $40 \mathrm{l} / \mathrm{m}^{2}$ and throughoutly mixed. Mycelium growth from infected roots collected from the treated soils was reduced to the same degree as chloropicrin treatment which was set up as the control.

3. Infected young plants of tea were dipped in the 2 fungicides (the same solutions stated in 2) for $24 \mathrm{hr}$ and replanted. After 6 or 12 monthes, it was found that the dipping treatment markedly inhibited the development of rhizomorpha of the causal fungus around the root.

4. From the results of these experiments, it was concluded that the soil treatment of these 2 fungicides and dipping infected plant in the solutions of them were both effective for control of the disease.

(Feb. 25, 1976) 